\title{
Management of Contaminant Mycoflora of Oyster Mushroom (var-Pleurotus florida) with Botanicals and GRAS Chemicals
}

\author{
Kala Chhetri*, Daisy Senapoty and D.K. Sharma \\ Mycology Research Section, Department of Plant Pathology, Assam Agricultural University, \\ Jorhat 78501, India \\ *Corresponding author
}

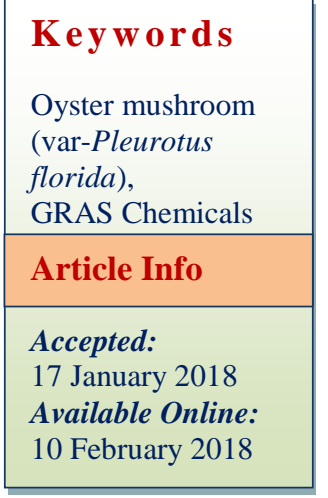

\section{Introduction}

The cultivation of mushroom is a carefully controlled biological system however, contamination with microorganisms is inevitable. Despite of several advantages of its cultivation, mushroom cultivation has not picked up to the desired momentum due to the
Contamination of Oyster mushroom (var Pleurotus florida) bed with harmful fungi Trichoderma harzianum and Aspergillus flavus caused complete failure of mushroom crop. Management of T.harzianum and A. flavus was investigated by using four botanicals plant extracts viz.,Neem, Tulshi, Boas and Methi seed @ 5\%,10\%,20\% concentration and GRAS chemicals viz., Boric acid, Calcium chloride, Sodium bi-carbonate and Sodium chloride@1\%,3\%,5\% concentration respectively along with control under in vitro condition. The result revealed that, Boric acid at 5\% concentration showed higher inhibition on mycelial growth of both fungus viz., T. harzianum (86.3\%)and A. flavus (82.55 \%)followed by boas Acorus calamus (51.44, 50.00\%) 20\% respectively. Also, methi seed Trigonella foenumgraecum inhibited mycelia growth of A.flavus $(43.66 \%)$ at $20 \%$ as compared to other treatments at all the concentration. Under in vivo evaluation, the application of Boas@20\%, Methi seed @20\%, Boric acid@ 5\% and Garlic (treated control)@4\% concentration increased the yield of mushroom significantly, with highest recorded yield i.e. $0.714 \mathrm{~kg} / \mathrm{bed}$ by application of $20 \%$ boas extract, which was at par with the yield treated with $4 \%$ garlic extract i.e. $0.691 \mathrm{~kg} / \mathrm{bed}$, followed by Boric acid at $5 \%$ concentration i.e. $0.565 \mathrm{~kg} / \mathrm{bed}$ and Methi at $20 \%$ concentration i.e. $0.516 \mathrm{~kg} / \mathrm{bed}$ respectively. Two most promising botanicals, Acorus calamus and Trigonella foenumgraecum was found to minimize the infection of mold in Oyster mushroom beds both in vitro and in vivo treatments. Under in vitro trial boric acid was found most effective to control mold infection. However, in vivo trial revealed that maximum yield was obtained from the bed treated with Acorous calamus. 
microflora generally result in delayed cropping, lesser yield, production of poor quality mushroom and even complete crop failure if the infection took place at the early stage of spawn run; warranting effective management measures. From the perusal of literatures it has been observed that in Assam detailed information about these competitor microflora especially on their relative importance, epidemiology and management aspects is very meagre. The mushroom farmers of the state generally use synthetic chemical fungicides to save their crop from foreign micro-organisms which may directly or indirectly also inhibit the growth of mushroom mycelia during spawn run on the substrate. As mushroom themselves are fungi and most of the competitor microflora are also fungi, it makes the choice of fungicides very difficult. Moreover, repeated and regular application of the same fungicide may greatly increase the chance of development of resistant mutants of microflora, resident toxicity, food poisoning, environmental pollution etc. in near future.

Under such circumstances, the present investigation has been undertaken to study the effect of seasonal fluctuations on the incidence of contaminant microflora, their management with botanicals and GRAS chemicals with a hope that it will be of vital significance. Although, several reports were published under antifungal principles of botanicals inhibiting the growth of other plant pathogens (Singh et al., 1993 ; Anthony et al., 2003 ;Ahmed et al., 2000), very less information is available on the management of contaminant microflora of mushrooms using plant extracts (Siddique et al., 2000; Narzari et al., 2007). Besides the botanicals, GRAS chemicals are also reported to possess antifungal substances that inhibit the plant pathogens (Mann et al., 2004; Qin et al., 2007; Deliopoulos et al., 2008; Deliopoulos et al., 2010), from the perusal of the literature it was seen that no work was done on the management of contaminant microflora of mushrooms using these GRAS chemicals. Therefore, the present report is made for the first time. The results of the various experiments pertaining to the present investigations are discussed in this paper.

\section{Materials and Methods}

\section{Cultivation of oyster mushroom}

Mushroom culture of Pleurotus florida, $\left(\mathrm{T}_{1}\right.$ generation) was collected from the Mycology Research Section, Department of Plant Pathology, Assam Agricultural University, Jorhat, and the culture was maintained in PDA during the course of investigation. The mushroom beds were raised in the mushroom house of Mycology Research Section, Department of Plant Pathology, AAU, Jorhat, by following the cultivation method of Rathaiah and Gogoi (1993). The beds were prepared on first week of the month starting from September-March and allowed for spawn running. Daily inspection was made to trace any growth of unwanted microflora on the beds till harvesting of the mushrooms. The incidence of contaminated (infected) beds were recorded as the number of infected beds out of the total beds rose in mushroom house and expressed in percentage.

\section{Isolation and identification of contaminant microflora}

Infected straws was collected from contaminated beds and cut into small pieces. The pieces were surface sterilized with 0.1 per cent Sodium hypochlorite $(\mathrm{NaOCl})$ for two minute and then rinsed with three changes of sterilized distilled water. Each piece was inoculated into PDA plates aseptically. The inoculated plates were incubated at $25 \pm 1^{\circ} \mathrm{C}$ for 3-7 days. Periodic sub-culture of the contaminants was done regularly into PDA plates during the period of investigation. A portion of fungal mass was 
observed under a compound microscope and mycological features like cultural character, hyphal characteristics, septations, branching pattern of hyphae, differentiation and development of sporophore, measurements etc were studied and compared with the relevant literatures for identification of the microflora isolated from contaminated mushroom beds.

\section{Collection of botanicals}

Different plant parts like fresh leaves, rhizome and seeds of four selected botanicals were collected from the various localities of Jorhat and campus of Assam Agricultural University for the preparation of aqueous plant extracts. Different botanicals used against contaminant microflora are listed in Table 1.

\section{Collection and preparation of phyto- extracts}

Different plant parts like fresh leaves, rhizome and seeds of four selected botanicals were collected from the various localities of Jorhat and campus of Assam Agricultural University (Table 1) and washed thoroughly in sterile distilled water. One hundred grams of washed plant parts was ground in prechilled mortar and pestle by adding equal amount $(100 \mathrm{ml})$ of sterilized distilled water $(1: 1 \mathrm{w} / \mathrm{v})$. After grinding, the extract was filtered through muslin cloth, then finally through Whatman No.1 filter paper and the filtrate was centrifuged at $10,000 \mathrm{rpm}$ for 20 minutes in Centrifuge at room temperature. The supernatant were taken as standard plant extract solution (100\%) (Shiddique et al., 2004).The extract was further diluted to different concentrations viz., 5, 10 and 20 per cent with sterile distilled water.

\section{Preparation of GRAS chemical solutions}

Four $100 \mathrm{ml}$ conical flasks were filled with distilled water. Calculated amount (i.e. 1, 3 and $5 \mathrm{~g}$ ) of each salts viz., sodium chloride, calcium carbonate, sodium hydrogen carbonate and boric acid (Table 2) were weighted and added to each flasks making the concentration (i.e. 1, 3 and 5 per cent) of the solution.

\section{In vitro test of phyto-extract and GRAS chemicals against isolated contaminant microflora}

Poison food technique (Finholt, 1951; Grover and Moore, 1962) was followed for in vitro study. In this studies computed amount of extracts was added to the growth medium (molten PDA) just prior to platting by means of sterile pipette under aseptic condition. Separate pipette were used for each concentration (i.e. 5, 10 and 20 per cent). Then the molten PDA medium with the extract was thoroughly mixed in a conical flasks and about $20 \mathrm{ml}$ of this mixture was dispensed in each Petridish of $9 \mathrm{~cm}$ in diameter. A mycelial disk were prepared using a cork borer (5mm diameter) from the tip of the 5-7days old culture of contaminant fungi one disk of the contaminant fungi was placed at the centre of the Petridishes after solidification of the medium containing phyto-extract. Three replications for each treatment were maintained. The basal medium (PDA) without any phyto-extract was served as control. All the inoculated Petridishes were incubated at $28 \pm 1^{\circ} \mathrm{C}$. The mycelia growth of the fungi in the treated plates was measured when the mycelia touched the periphery $(9 \mathrm{~cm}$ dia.) in the control Petridish.

The mycelial growth of contaminant microflora was calculated by the formula of Vincent (1927).

$I=\frac{(C-T)}{C} \times 100$

Where, $\mathrm{I}=$ Percent inhibition of mycelial 
growth

$\mathrm{C}=$ Mycelial growth in control

$\mathrm{T}=$ Mycelial growth in treatment

\section{Efficacy of botanicals and GRAS chemicals on mould and mushroom yield}

Based on the preliminary screening of both botanicals and GRAS chemicals, two effective botanical and one GRAS chemical was selected to carry out the experiment. The experimental details are $\mathrm{T}_{1}$ and $\mathrm{T}_{2}=$ two best effective botanical, $\quad \mathrm{T}_{3}=$ bestGRAS chemical, $\mathrm{T}_{4}=$ Allium sativum @4\% (treated control) and $\mathrm{T}_{5}=$ Control (without any phytoextract or any chemical). The statistical analysis was carried out using Completely Randomized Design (CRD) with five replication. The phyto-extract and GRAS chemical was sprayed before spawning on the pasteurized rice straw. A control set was maintained without any spray of the phytoextracts and GRAS chemical. In addition to the phyto-extracts, Garlic (4\%) treated control was also sprayed in another set for comparison. The totals of five treatments were brought to mushroom beds including control.

The beds were incubated in partially dark room of the mushroom house. Beds were opened after 15-18 days of spawn run and the total yield of 2 flushes in each treatment was recorded.

The phyto-extract and GRAS chemical at specified concentrations was sprayed on the mushroom beds at the time of opening. After opening, a control set was maintained without application of phyto-extract and GRAS chemical. Garlic extract @ 4\% (treated control) was also sprayed in another set for comparison. Five replications were maintained in each treatment. Finally total yield from each treatment was recorded and per cent yield increase over control was estimated

\section{Results and Discussion}

In the present study, the incidence of contaminants was maximum during the month of September and resulted in highest yield loss. The experiment revealed that Trichoderma harzinum and Aspergillus flavus were the major contaminants of mushroom beds which could cover up the beds very rapidly and restricted the mycelia run in the pasteurized straw even after spawning with good quality spawn. Similarly, Anandh et al., (1999) reported Aspergillus niger, Aspergillus flavus and Trichoderma harzianum are the important contaminants of Pleurotuseous (berk) sacc beds. Rai et al., (1993) isolated 23 weed fungi from cultivated beds of Pleurotus sajorcaju. Out of these, Trichoderma viride, Aspergillus niger var., Tieghem, Alternaria alternate, Cochliobolus specifer, Fusarium oxysporum Schl.ex Fr. Penicillum oxalicum series, Rhizopus stolonifer (Ehrenb) Lind and Sclerotiumrolfsii were most harmful. Trichoderma, Aspergillus and Rhizopus on oyster mushroom bed were predominant microorganisms (Jaivel and Marimuthu, 2010).Recently, M. and G. Uma Devi (2016) also reported that the major contaminants recorded were of fungal species viz., Aspergillus niger, Aspergillus flavus and Trichoderma spp in different mushroom species.

\section{In vitro evaluation of botanicals and GRAS} chemicals against contaminant microflora

In vitro result revealed that the aqueous extracts of all the botanicals were significantly effective in inhibiting the mycelia growth of contaminant microflora in comparison to control (Table 3). Among the four botanical extracts tested, Acorus calamus (Bos) expressed the strongest antifungal activity against $T$. harzianum, followed by Trigonella foenumgraecum (Methi), Ocimum sanctum (Tulsi) and Azadiracta 
indica (Neem) at 20 per cent concentration. Leaf extracts of, Azadiracta indica, Trigonella foenumgraecum and Ocimum sanctum were less effective. Lee and his co worker in2004 also reported that Acorus calamus inhibited the mycelial growth of Cladosporium cucurmerianum, $C$. Orbiculare, Magnaporthegrisea and Pythium ultimum. The rhizomes of A. calamus been reported to possess several important biological activities including antifungal (Lee etal., 2004), antibacterial (Mc. Grawet al. 2002),allelopathic, insecticidal and pesticidel (Nalamwar et al, 2009). On the other hand, the In vitro evalution of GRAS chemicals against contaminant microflora viz., $T$. harzianum and Aspergillus flavus revealed that all the chemicals were effective in inhibiting the mycelia growth of both the contaminant as compared to control(Table 4 and Table 5). Among the four chemicals tested, Boric acid expressed the strongest antifungal activity against $T$. harzianum and Aspergillus flavus at $5 \%$ concentration which might be due to the presence of non volatile mineral having insecticidal, fungicidal and herbicidal properties. Moreover, boric acid has been reported to efficiently control of disease in grapevine caused by Eutypalata Rolshausen and Gubler (2005). Qin et al., (2001) have reported that boron was effective to inhibit the growth of Penicillium expansum.

Table.1 List of botanicals used against the contaminant microflora of oyster mushroom, Pleurotus florida $(\mathrm{Fr})$

\begin{tabular}{|c|l|c|c|c|c|l|l|}
\hline Sl. No. & Scientific name & Vernacular name & Local name & \multicolumn{1}{|c|}{ Family } & Plant parts used & \multicolumn{1}{|c|}{ Chemical constituent } & \multicolumn{1}{|c|}{ References } \\
\hline $\mathbf{1 .}$ & $\begin{array}{l}\text { Azadirachta } \\
\text { indica } \text { A. Juss }\end{array}$ & $\begin{array}{c}\text { Margosa or neem } \\
\text { tree }\end{array}$ & Neem & Meliaceae & Leaves & $\begin{array}{l}\text { Nimbin, Nimbidin and } \\
\text { Nimbidol }\end{array}$ & $\begin{array}{l}\text { Rastogi and } \\
\text { Mehrotra1960,1969 }\end{array}$ \\
\hline $\mathbf{2 .}$ & $\begin{array}{l}\text { Ocimum sanctum } \\
\text { L. }\end{array}$ & Holy basil & Tulsi & Lamiaceae & Leaves & $\begin{array}{l}\text { Eugenol, Ocimene,cadinene } \\
\text { and perillyl alcohol }\end{array}$ & $\begin{array}{l}\text { Rastogi and } \\
\text { Mehrotra1960,1969 }\end{array}$ \\
\hline $\mathbf{3 .}$ & $\begin{array}{l}\text { Trigonella } \\
\text { foenumgraecum } \\
\text { L. }\end{array}$ & Methi & Methi & Fabaceae & Seeds & $\begin{array}{l}\text { Trigonelline,fenugreekine,g } \\
\text { entianine andcarpaine } \\
\text { compounds }\end{array}$ & $\begin{array}{l}\text { Mullaicharam and } \\
\text { Geetali Deori, 2013 }\end{array}$ \\
\hline $\mathbf{4 .}$ & $\begin{array}{l}\text { Acorus calamus } \\
\text { L. }\end{array}$ & Boas & Boas & Acoraceae & Rhizome & $\begin{array}{l}\text { B-Asarone(isoasarone), } \alpha- \\
\text { Asarone, } \\
\text { elemicine,isoeugenol. }\end{array}$ & $\begin{array}{l}\text { Kumar Amit and } \\
\text { Vandana, 2013 }\end{array}$ \\
\hline
\end{tabular}

Table.2 List of GRAS chemical used against the contaminant microflora of oyster mushroom, Pleurotus florida $(\mathrm{Fr})$

\begin{tabular}{|c|l|l|c|c|c|c|}
\hline Sl. No. & IUPAC Name & \multicolumn{1}{|c|}{ Other name } & Chemical formula & Molecular weight $(\mathbf{g} / \mathbf{m o l})$ & Density $\left(\mathbf{g} / \mathbf{c m}^{3}\right)$ & \multicolumn{1}{|c|}{ Appearance } \\
\hline $\mathbf{1 .}$ & Sodium chloride & Rock salt, Common salt & $\mathrm{NaCl}$ & 58.44 & 2.163 & Colourless \\
\hline 2. & Calcium carbonate & Calcite, chalk, limestone & $\mathrm{CaCO}_{3}$ & 100.08 & 2.711 & $\begin{array}{l}\text { Fine white powder; } \\
\text { chalky taste }\end{array}$ \\
\hline 3. & $\begin{array}{l}\text { Sodium hydrogen } \\
\text { carbonate }\end{array}$ & $\begin{array}{l}\text { Baking soda, bicarbonate } \\
\text { of soda }\end{array}$ & $\mathrm{NaHCO}_{3}$ & 84.00 & 1.1 & White crystals \\
\hline 4. & Boric acid & $\begin{array}{l}\text { Orthoboric acid, Boracic } \\
\text { acid. Borofax }\end{array}$ & $\mathrm{H}_{3} \mathrm{BO}_{3}$ & 61.83 & 1.435 & $\begin{array}{l}\text { White crystalline } \\
\text { solid }\end{array}$ \\
\hline
\end{tabular}


Management of contaminant microflora using botanicals and GRAS chemicals

Based on the in vitro effectiveness, $A$. calamus, T. graceum at $20 \%$ concentration and boric acid at $5 \%$ concentration were selected and tested along with garlic extract at $4 \%$ concentration on the mushroom bed of $P$. florida against contaminant microflora. Data indicated that $A$. calamus over all the treatment yield maximum at $20 \%$ concentration, followed by garlic extract, boric acid and $T$. graceum respectively (Table 6). The yield of mushroom beds sprayed with bos extract @ 20 per cent concentrationwas significantly superior over control compared to all other treatments. In all the four treatment, spraying with bos extract at 20 per cent gave significantly higher yield followed by boric acid at 5 per cent concentration and methi extract at 20 per cent concentration. However, the yield of mushroom at 20 per cent and 4 percent garlic extract (treated control) were $0.714 \mathrm{~kg} / \mathrm{bed}$ and $0.691 \mathrm{~kg} / \mathrm{bed}$, respectively which were not significantly different at 0.05 per cent $C D$ level. An increase in yield of 89.38 per cent over control (untreated control) was obtained with bos at 20 per cent concentration followed by boric acid 49.86 at 5 per cent concentration and 36.87 per cent with methi at 20 per cent concentration. Lee et al., 2004, reported that Acorus calamus inhibited the mycelial growth of Cladosporium cucurmerianum, $C$. Orbiculare, Magnaporthegrisea and Pythium ultimum. The rhizomes of A calamus been reported to possess several important biological activities including antifungal (Lee et al., 2004), antibacterial (McGraw et al. 2002), allelopathic, insecticidal and pesticidel (Nalamwar et al, 2009).Ghosh (2006) reported efficacy of a pathogenesis related protein, haem peroxidise extracted from $A$. calamus leaves against phytopathogens such as Macrophomina phaseolina, Fusarium moniliforme and Trichosporium vesiculosum.
Rhizome and leaves extract of sweet flag showed marked antifungal activity against Aspergillus niger, A. flavus (Devi et al., 2009).

In conclusion, the present investigation has shown effective results in using plant extracts and GRAS chemicals against contaminant microflora of oyster mushroom in beds. The use of plant extracts and GRAS chemicals identified offers a cheaper and environmentally safer alternative to fungicide for application in mushroom beds against contaminant microflora viz., T. harzianum and Aspergillus flavus. The botanicals viz., Acorus calamus and Trigonella foenumgraecum has scope for commercial exploitation for management of contaminant microflora of mushroom beds. The study also showed encouraging results in using GRAS chemicals against contaminant microflora of mushroom beds. These can be considered as promising alternative to use of synthetic fungicides.

\section{Acknowledgement}

The author is grateful to the Assam Agricultural University, Jorhat and Depatment of Plant Pathology, Jorhat, Assam for providing necessary facilities.

\section{References}

Anandh, K.; Ramanujan, K. and Peakasam, V. (1999). Estimation of yield loss of pleurotuseous caused by contaminants. J. Mycol. Pl. Pathol. 29: 333-335.

Devi, Asha. And Ganjewala, Deepak. (2009) . Antimicrobial activity of Acoruscalamus rhizome and leaf extract. Acta Biologica Szegediensis, 53(1): 45-49.

Finholt, R. W. (1951). Improved Toximetric Agar-dish Test for Evaluation of Wood Preservatives. Anal. Chem. 23:10391039. 
Ghosh, M. (2006). Antifungal properties of haem-peroxidase from Acoruscalamus. Ann Bot .98: 1145-1153.

Grover, R.K., Moore, J.D. (1962). Toxicometric studies of fungicides against brown rot organisms Sclerotinia fructicola and $S$. laxa. Phytopathoogy.52: 876-880.

Jaivel, N. and Marimuthu, P. (2010). Strain improvement of Aspergillus terrus for increased lovastatin production. Int. J. Eng. Sci. Technol. 2(7): 2612-2615.

Lee, J.Y.; Yun, B.S. and Hwang, B.K. (2004). Antifungal activity of Basaronerhi- zomes of Acorus gramineus. J.Agril.Food.Chem. 52: 776-78.

McGaw, L.J.; Jager, A.K., and Van Staden, J. (2002). Isolation of B-asarone, an antibacterial and anthelmintic compound, from Acorus calamus in South Africa. South African. J Bot .68: 31-35.

Nalamwar, V. P.; Khadabadi, S. S.; Aswar, P.
B.; Kosalge, S. B. and Rajurkar, R. M. (2009), "In Vitro Licicidal Activity of Different Extracts of Acorus calamus Linn. (Araceae) Rhizome", Int. J. Pharm. Tech. Res., pp.1: 96-100.

Prameela, M. and Uma Devi, G. (2016). Occurrence of Different Mycoflora in Oyster Mushrooms and their Management. Intern. J. Trop. Agril.34(4): 943-946

Quarles, W. (2001). Boric acid, Borates and Household Pests. The IPM Practioner. 23: 1-12.

Rai, R. D.; Vijay, B. and Saxena, S. (1993). Mushroom Res., 2: 49 - 52.

Rathaiah, Y. and Gogoi, R. (1993). Oyster mushroom Cultivation in Assam. Dept. of Plant Pathology, Assam Agricultural University, Jorhat, Assam, pp. 10.

Rolshausen, P.E. and Gubler, W.D. (2005). Use of Boron for the control of Eutypa Dieback of Grapevines. Plant Dis. 89: 734-738.

\section{How to cite this article:}

Kala Chhetri, Daisy Senapoty, Sharma, D.K. 2018. Management of Contaminant Mycoflora of Oyster Mushroom (var-Pleurotus florida) with Botanicals and GRAS Chemicals. Int.J.Curr.Microbiol.App.Sci. 7(02): 1972-1978. doi: https://doi.org/10.20546/ijcmas.2018.702.236 